\title{
EVALUASI ATASAN TERHADAP VARIABEL YANG MEMPENGARUHI KECENDERUNGAN KECURANGAN BAWAHAN DALAM PENGADAAN BARANG/JASA
}

\author{
Agus Sunarmo ${ }^{*}$, Puji Lestari ${ }^{1}$, dan Ayunisa Wilistia ${ }^{1}$ \\ ${ }^{1}$ Jurusan Akuntansi, Fakultas Ekonomi dan Bisnis, Universitas Jenderal Soedirman, Indonesia \\ *email corresponding author: as.narmo@gmail.com
}

\begin{abstract}
Abstrak
Dalam Peraturan Presiden Republik Indonesia Nomor 16 Tahun 2018 disebutkan bahwa pengadaan barang/jasa adalah kegiatan pengadaan barang atau jasa oleh Kementerian atau Lembaga atau Perangkat Daerah yang dibiayai oleh Anggaran Pendapatan dan Belanja Negara (APBN) atau Anggaran Pendapatan dan Belanja Daerah (APBD) dengan serangkaian proses mulai dari identifikasi kebutuhan sampai dengan serah terima hasil pekerjaan. Kepastian dan ketepatan pengadaan barang/jasa membutuhkan pengendalian dari setiap aspek untuk mengeliminasi penyimpangan terhadap pencapaian tujuan pengadaan barang/jasa. Secara melekat, pengendalian tersebut dilakukan oleh atasan melalui penilaian yang cermat setiap aspek dalam serangkaian proses pengadaan barang/jasa. Tanggapan atasan terhadap variable yang mempengaruhi ketepatan dan kepastian unjuk kerja bawahan dalam melaksanakan serangkaian proses pengadaan barang/jasa menjadi hal penting untuk dievaluasi. Variabel penting tersebut antara lain pengendalian internal, budaya organisasi, komitmen organisasi, kompetensi, dan ketaatan aturan. Data tanggapan atasan mengenai variabel yang mempengaruhi penyimpangan pencapaian tujuan pengadaan barang/jasa dikumpulkan secara langsung melalui kuesioner dengan menggunakan sampling jenuh dengan responden Pejabat Pembuat Komitmen (PPK) dari 28 OPD yang diwakili oleh satu hingga empat responden setiap unit OPD. Analisis menggunakan regresi linear berganda dengan bantuan aplikasi Software SPSS 16.0 for windows. Hasil penelitian menunjukkan bahwa pengendalian internal, budaya organisasi, komitmen organisasi, kompetensi dan ketaatan aturan secara tidak searah (negatif) berpengaruh signifikan terhadap kecenderungan kecurangan bawahan dalam pengadaan barang/jasa.
\end{abstract}

Kata Kunci: Variabel Yang Mempengaruhi Kecurangan, Kecenderungan Kecurangan, Pengadaan Barang/Jasa.

\begin{abstract}
In the Presidential Regulation of the Republic of Indonesia Number 16/2018 it is stated that the procurement of goods/services is the activity of procurement of goods or services by Ministries or Institutions or Regional Apparatuses financed by the State Budget (APBN) or the Regional Budget (APBD) in a series of the process starts from identifying needs to handing over the work. The certainty and accuracy of the procurement of goods/services requires control from every aspect to eliminate deviations from achieving the objectives of the procurement of goods/services. Adherently, this control is carried out by superiors through careful assessment of every aspect in a series of goods/services procurement processes. Responses from superiors to variables that affect the accuracy and certainty of subordinates' performance in carrying out a series of goods/services procurement processes are important to evaluate. Important variables include internal control, organizational culture, organizational commitment, competence, and obedience to the rules. Data from superiors' responses regarding variables that influence deviations in achieving goods/service procurement goals are collected directly through a questionnaire using saturated sampling with respondents Pejabat Pembuat Komitmen (PPK) from 28 OPDs represented by one to four respondents per OPD unit. Data analyzed using multiple linear regressions with assisted by SPSS 16.0 for Windows. The results showed that the influence variables (internal control, organizational culture, organizational commitment, competence and obedience to the rules) had a significant negative effect on the tendency of subordinate fraud in the procurement of goods/services.
\end{abstract}

Keywords: Influence Variables, Tendency of Fraud, Procurement of Goods/Services 


\section{PENDAHULUAN}

Peningkatan pelayanan publik oleh instansi pemerintah dapat dilakukan dengan menyediakan sarana dan prasarana yang menunjang kinerja. Sebagai langkah untuk meningkatkan kinerja pemerintahan, pengadaan barang/jasa menjadi salah satu program yang harus dilaksanakan oleh setiap Organisasi Perangkat Daerah (OPD) dengan mengalokasikan dana dari APBD. Dalam Peraturan Presiden Republik Indonesia Nomor 16 Tahun 2018, pengadaan barang/jasa adalah kegiatan pengadaan barang atau jasa oleh Kementerian atau Lembaga atau Perangkat Daerah yang dibiayai oleh Anggaran Pendapatan dan Belanja Negara (APBN) atau Anggaran Pendapatan dan Belanja Daerah (APBD) yang memiliki rangkaian proses identifikasi kebutuhan hingga serah terima hasil pekerjaan. Panitia pengadaan barang/jasa terdiri dari orang-orang yang mampu dan mempunyai kompetensi dalam bidang pengadaan barang/jasa dan mempunyai wewenang sebagai pelaksana maupun pengawas dalam kegiatan pengadaan barang/jasa. Panitia pengadaan barang/jasa terdiri dari Pengguna Anggaran (PA), Kuasa Pengguna Anggaran (KPA), Pejabat Pembuat Komitmen (PPK), Pejabat Pengadaan, Pejabat Penerima Hasil Pekerjaan (P2HP), dan Pejabat Pelaksana Teknik Kegiatan (PPTK).

Tren penindakan kasus korupsi pengadaan barang/jasa pada tahun 2016 dan 2017 menurut hasil survey Indonesia Corruption Watch (ICW) menunjukkan bahwa kasus korupsi yang terjadi sebanyak 436 kasus dengan jumlah tersangka 245 orang yang merupakan bagian dari panitia pengadaan barang/jasa. Kasus korupsi pengadaan barang/jasa yang terjadi di pemerintah kabupaten sebanyak 222 kasus dengan total kerugian negara mencapai Rp 1.170.000.000.000 dengan modus korupsi antara lain berupa penyalahgunaan anggaran, mark up, kegiatan fiktif, penyalahgunaan wewenang dan laporan fiktif. Hasil survey ICW semester 1 tahun 2018 menujukkan bahwa rata-rata total kerugian negara meningkat dari 2 tahun sebelumnya yakni mencapai Rp 7.800.000.000 dengan jumlah aktor/tersangka dalam kasus korupsi pengadaan barang/jasa turun sebanyak 59 persen dari tahun sebelumnya.

Kabupaten Cilacap merupakan salah satu dari 9 kabupaten dan 3 kota yang berhasil meraih opini Wajar Tanpa Pengecualian (WTP) setelah pada tahun sebelumnya meraih opini Wajar Dengan Pengecualian (WDP) menurut hasil audit Badan Pemeriksa Keuangan (BPK) terhadap Laporan Keuangan Pemerintah Daerah (LKPD) pada tahun anggaran 2015 dan 2016. Sejak tahun anggaran 2005 hingga 2015 Kabupaten Cilacap selalu mendapat opini WDP dengan temuan sistem pengendalian internal yang lemah dan ketidakpatuhan terhadap perundangundangan (BPK RI, 2017). Hasil audit operasional terhadap hasil Program Kerja Pengawasan Tahunan (PKPT) tahun 2017 dan semester 1 tahun 2018 ditemukan 630 temuan disertai dengan 632 rekomendasi antara lain: kekurangan volume pekerjaan pada pembangunan fisik, harga yang terlalu mahal melebihi standar satuan harga dan pertanggungjawaban dana yang tidak didukung bukti memadai dalam proses pengadaan barang/jasa (Suara Merdeka, 2018).

Kasus-kasus kecurangan dalam pengadaan barang/jasa menunjukkan bahwa masih ada celah dalam proses perencanaan hingga pelaksanaan yang memungkinkan seseorang memanfaatkannya untuk memperoleh keuntungan secara pribadi dan menyalahgunakan prinsip yang sudah dituangkan dalam peraturan. Dalam Peraturan Presiden Republik Indonesia Nomor 16 Tahun 2018 disebutkan tentang prinsip pengadaan barang/jasa yaitu efisien, efektif, transparan, terbuka, bersaing adil dan akuntabel. Kecurangan dalam pengadaan barang/jasa tidak hanya dilakukan karena alasan kepentingan individu saja, namun dapat dilakukan karena alasan kepentingan bersama dari sejumlah oknum.

Berdasarkan latar belakang tersebut, menarik untuk dikaji tentang variabel yang mempengaruhi (pengendalian internal, budaya organisasi, komitmen organisasi, kompetensi dan ketaatan aturan) kecenderungan kecurangan bawahan dalam pengadaan barang/jasa.

\section{TINJAUAN PUSTAKA DAN PERUMUSAN HIPOTESIS}

\section{Tinjauan Pustaka \\ Fraud Theory}

Association of Certified Fraud Examiner (ACFE) menjelaskan bahwa fraud adalah perbuatan melawan hukum dan dilakukan secara sengaja untuk mencapai tujuan tertentu dan 
dilakukan oleh orang yang berada di dalam organisasi atau di luar organisasi guna mendapatkan keuntungan pribadi atau kelompok secara langsung maupun tidak langsung. Teori tentang fraud berkembang sesuai dari Fraud Triangle Theory, Fraud Diamond Theory, dan Fraud Pentagon Theory. Teori fraud triangle menurut Cressey (1953) menjelaskan 3 faktor yang menyebabkan seseorang melakukan kecurangan yaitu Tekanan (Pressure), Kesempatan (Opportunity), dan Rasionalisasi (Rationalization).

Teori fraud diamond merupakan pengembangan dari teori fraud triangle. Wolfe dan Hermanson (2004) menyatakan bahwa fraud tidak akan terjadi pada suatu organisasi apabila tidak ada orang yang mempunyai kemampuan khusus dan dapat melakukan kecurangan. Kemampuan (capability) seseorang atau sifat yang dimiliki individu mempunyai peranan penting dalam menentukan apakah individu tersebut akan cenderung melakukan kecurangan atau tidak.

Dalam teori fraud pentagon, Crowe (2011) menambahkan elemen baru yaitu arogansi (arrogance) yang merupakan sikap superioritas atas hak yang dimiliki dan merasa bahwa pengendalian internal tidak berlaku bagi individu tersebut. Individu akan menganggap dirinya lebih unggul dan menganggap bahwa kebijakan dapat dilanggar untuk dirinya dan dapat dengan mudah melakukan kecurangan.

\section{Fraud Tree Theory}

Dalam fraud tree (Singleton et al, 2006), sistem klasifikasi berbagai bentuk kecurangan dibagi menjadi 3 jenis yaitu: a) Korupsi (Corruption), Korupsi adalah kecurangan yang dilakukan oleh satu atau dua orang guna mendapatkan keuntungan. Korupsi terdiri dari empat hal yaitu benturan kepentingan (conflict of interest) antara panitia pengadaan barang/jasa dan penyedia barang/jasa, penyuapan (bribery) misalnya penyedia barang/jasa mengintervensi pemilihan tender dalam pengadaan barang/jasa, pemberian hadiah yang terselubung (illegal gratuities) seperti hadiah yang diberikan oleh penyedia barang/jasa kepada panitia pengadaan barang/jasa, dan pemerasan (economic extortion) yang dilakukan secara terselubung maupun secara terbuka terhadap penyedia barang/jasa, b) Penyalahgunaan Aset (Asset Misappropriation)

Penyalahgunaan aset meliputi pencurian aset atau pengambilan aset secara ilegal yang dilakukan dalam beberapa bentuk, c) Kecurangan Laporan (Fraudulent Statement), Kecurangan laporan mengenai penyajian laporan keuangan berupa salah saji yang menyebutkan understatement maupun overstatement serta kecurangan penyajian laporan non keuangan.

\section{Teori Persepsi Diri (Self Perception Theory)}

Persepsi menurut Luthans (1991) adalah suatu intensi yang sulit dan terdiri dari kegiatan seleksi, penyusunan dan penafsiran. Persepsi diri adalah upaya mengamati dan mengenali motivasi, sifat, perasaan dan emosi untuk memperoleh informasi tentang lingkungannya. Individu yang dapat mempersepsikan dirinya dengan baik berarti mempunyai kesadaran akan diri sendiri dengan baik. Individu akan mempersepsikan dirinya dengan melihat perilakunya dalam berkegiatan sehari-hari.

\section{Pengadaan barang/jasa}

Tahapan dalam prosedur pengadaan barang/jasa menurut Peraturan Presiden Nomor 16 Tahun 2018 meliputi perencanaan pengadaan barang/jasa, persiapan pengadaan barang/jasa dan pelaksanaan pengadaan. Perencanaan pengadaan dilakukan dengan mengidentifikasi kebutuhan, penetapan barang/jasa, metode, jadwal dan anggaran yang diperlukan. Hasil dari perencanaan akan dimuat dalam Rencana Umum Pengadaan (RUP) dan ditetapkan oleh pengguna anggaran. Tahap persiapan pengadaan barang/jasa dilakukan sesuai metode yang sudah ditetapkan sebelumnya yaitu melalui swakelola atau penyedia. Dalam tahap pelaksanaan pengadaan barang/jasa, pelaksana harus melaporkan kemajuan pelaksanaan pengadaan barang/jasa.

\section{Pengendalian Internal}

Menurut Committee of Sponsoring Organizations of the Treadway Commission (COSO), pengendalian internal merupakan proses yang dilakukan oleh seluruh lapisan manajemen dan dirancang untuk memberikan jaminan mengenai pencapaian tujuan. Komponen pengendalian internal menurut COSO dan sebagaimana disebutkan dalam Peraturan Pemerintah Nomor 60 
Tahun 2008 pasal 3 terdiri dari 5 unsur yaitu Lingkungan Pengendalian, Penilaian Risiko, Kegiatan Pengendalian, Informasi dan komunikasi serta Pemantauan.

\section{Budaya Organisasi}

Budaya organisasi Trefry (2006) dapat didefinisikan dalam dua tingkat yaitu tentang bagaimana tugas-tugas diselesaikan dan tentang kepercayaan dan nilai yang ada di organisasi tersebut. Budaya organisasi menggambarkan karakteristik dari organisasi tersebut, apabila suatu organisasi mempunyai budaya yang etis maka karyawan yang bekerja cenderung akan patuh terhadap peraturan-peraturan yang berlaku (Virmayani et al, 2017).

\section{Komitmen Organisasi}

Komitmen organisasi adalah penerimaan seseorang terhadap nilai dan tujuan organisasi, sikap seseorang dalam organisasi yang berkaitan dengan pencapaian tujuan akan menunjukkan seberapa besar komitmennya terhadap organisasi tersebut (Najahningrum, 2013).

\section{Kompetensi}

Kompetensi (Mathis dan Jackson, 2011) merupakan karakteristik dasar yang dihubungkan dengan pencapaian kinerja individu maupun tim yang terdiri dari pengetahuan (knowledge), keterampilan (skill), dan kemampuan (capability). Kompetensi adalah kemampuan individu dalam melakukan pekerjaan yang dilandasi pengetahuan, keterampilan dan sikap kerja. Wolfe dan Hermanson (2004) menjelaskan bahwa sifat yang sangat penting dalam diri pelaku tindak kecurangan adalah intelligence dan creativity.

\section{Ketaatan Aturan}

Aturan adalah tindakan atau perbuatan yang harus dilakukan. Ketaatan aturan adalah sikap patuh dan tidak berlaku curang terhadap aturan yang sudah ditetapkan. Tarigan (2016) menyatakan jika suatu organisasi taat kepada aturan yang sudah ditetapkan maka dapat mencegah terjadinya kecurangan.

\section{Kecenderungan Kecurangan}

Beberapa fraud yang terjadi dalam kegiatan pengadaan barang/jasa (Jatiningtyas, 2011) antara lain: a) Ketidaksesuaian antara barang/jasa yang disetujui dalam kontrak dengan kebutuhan instansi/masyarakat dilihat dari jenis, kualitas maupun kuantitas barang/jasa. b) Ketidaksesuaian antara spesifikasi teknis barang/jasa yang telah diselesaikan oleh penyedia barang/jasa dengan spesifikasi teknis yang telah ditetapkan dalam kontrak, c) Ketidaksesuaian antara volume barang/jasa yang telah diselesaikan oleh penyedia barang dengan jumlah yang seharusnya sesuai dengan kontrak, d) Ketidakwajaran harga barang/jasa yang disepakati dalam kontrak, e) Keterlambatan penyelesaian pekerjaan oleh rekanan dari jadwal waktu yang telah ditetapkan dalam kontrak.

\section{Perumusan Hipotesis}

Dalam kepanitiaan pengadaan barang/jasa, Pejabat Pembuat Komitmen (PPK) berperan sebagai pengawas yang bertanggung jawab terhadap pelaksanaan pengadaan barang/jasa. Pengawasan oleh PPK dilakukan dengan menerapkan konsep pengendalian internal yakni lingkungan pengendalian, penilaian risiko, aktivitas pengendalian, informasi dan komunikasi, serta pemantauan secara periodik untuk memastikan bahwa panitia pengadaan dibawahnya bekerja sesuai prosedur dan ketentuan yang berlaku. Hasil penelitian Arifianti et al (2015); Astari (2018); dan Artini et al (2014) menunjukkan bahwa pengendalian internal berpengaruh tidak searah (negative) terhadap kecenderungan kecurangan. Hasil penelitian tersebut tidak berbeda dengan temuan BPK yang menyatakan bahwa sistem pengendalian internal yang baik mampu mengurangi tingkat kecurangan yang terjadi pada suatu organisasi (Kompasiana, 2016).

Budaya Organisasi menurut Virmayani et al (2017) merupakan sebuah sistem dari nilainilai yang bersifat umum. Budaya organisasi yang baik akan membentuk para pelaku organisasi mempunyai rasa memiliki (sense of belonging) dan rasa bangga (sense of identity) sedangkan budaya organisasi yang buruk akan mempengaruhi pelaku organisasi dalam melakukan kecurangan. Hasil penelitian Virmayani et al (2017) dan Fachrunisa (2015) menunjukkan bahwa budaya organisasi berpengaruh tidak searah (negatif) terhadap kecenderungan kecurangan. Hasil penelitian tersebut tidak berbeda dengan hasil penelitian Siregar dan Hamdani (2018) yang menyatakan bahwa penerapan budaya organisasi yang baik dapat meminimalisasi terjadinya kecenderungan kecurangan. 
Organisasi yang mempunyai anggota berkomitmen tinggi maka tingkat keberhasilan dalam pencapaian tujuan tinggi, hal ini disebabkan individu tersebut akan mementingkan kepentingan kelompok daripada kepentingan diri sendiri (Virmayani et al, 2017). Individu dalam hal ini, panitia pengadaan barang/jasa yang berkomitmen tinggi akan melaksanakan fungsi dan tanggung jawabnya dengan potensi yang rendah untuk melakukan kecurangan. Hasil penelitian Sumbayak et al (2017) dan Virmayani et al (2017) menunjukkan bahwa komitmen organisasi berpengaruh tidak searah (negatif) terhadap kecenderungan kecurangan. Hasil penelitian tersebut menyatakan bahwa komitmen organisasi yang kuat dapat mencegah terjadinya kecurangan.

Keputusan yang diambil panitia pengadaan barang/jasa adalah hal yang krusial karena harus dipertanggungjawabkan dalam akhir pelaksanaan kegiatan pengadaan barang/jasa (Jatiningyas, 2011). Menurut Yanavia (2014) kualitas atau kompetensi panitia pengadaan barang/jasa adalah faktor yang mempengaruhi keberhasilan suatu sistem pengadaan barang/jasa dalam mencapai tujuan yang telah ditetapkan. Kompetensi yang harus dimiliki oleh masing-masing jabatan dalam panitia pengadaan barang/jasa tercantum dalam Peraturan Presiden Republik Indonesia Nomor 16 Tahun 2018. Faktor yang mempengaruhi kecenderungan individu dalam melakukan kecurangan juga dapat dilihat dari seberapa kompeten individu tersebut dalam melakukan pekerjaannya (Wonar et al, 2018). Hasil penelitian Wonar et al (2018) menyebutkan bahwa kompetensi memiliki peran penting sehingga berpengaruh signifikan terhadap kecenderungan kecurangan.

Aturan tentang pengadaan barang/jasa tercantum dalam Peraturan Presiden Republik Indonesia Nomor 16 Tahun 2018 setelah melalui beberapa perubahan dari aturan sebelumnya. Pengadaan barang/jasa mempunyai prosedur dan ketentuan yang harus ditaati. Menurut Indriani et al (2016) penegakan aturan membutuhkan kesadaran dari individu yang terlibat supaya dapat berjalan sebagaimana mestinya. Dalam hal ini, panitia pengadaan barang/jasa harus melaksanakan fungsi dan wewenang mengikuti aturan yang berlaku. Hasil penelitian Chandra dan Ikhsan (2015); Zulkarnain (2013); dan Wijayanti (2016) menunjukkan adanya pengaruh tidak searah (negatif) antara ketaatan aturan/hukum terhadap kecenderungan kecurangan. Hasil penelitian tersebut berarti bahwa ketaatan aturan yang diterapkan pada suatu organisasi dapat menekan terjadinya kecurangan.

Berdasarkan rumusan tersebut, diajukan hipotesis penelitian: influence variable (variabel pengendalian internal, budaya organisasi, komitmen organisasi, kompetensi, dan ketaatan aturan) secara tidak searah (negatif) berpengaruh signifikan terhadap kecenderungan kecurangan dalam pengadaan barang/jasa.

\section{METODE PENELITIAN}

Penelitian ini merupakan penelitian survey dengan pendekatan pembahasan secara deskriptif kuantitatif. Objek penelitian adalah persepsi atasan (Pejabat Pembuat Komitmen/PPK) dalam mengevaluasi variabel yang mempengaruhi (influence variable) kecenderungan kecurangan akuntansi (fraud) bawahan (panitia pengadaan barang/jasa) yang meliputi variabel pengendalian internal, budaya organisasi, komitmen organisasi, kompetensi dan ketaatan aturan. Populasi penelitian meliputi seluruh (28 satuan dinas) Organisasi Perangkat Daerah (OPD) (PPID Kabupaten Cilacap, 2018). Pengambilan sampel menggunakan teknik sampel jenuh (saturated sampling technique). Responden penelitian ditentukan untuk setiap OPD diwakili oleh minimal 1 (satu) orang responden yaitu Pejabat Pembuat Komitmen (PPK) dalam Pengadaan Barang/Jasa.

\section{Teknik Analisis Data Statistik Deskriptif}

Statistik deskriptif merupakan proses pengumpulan serta peringkasan data guna menggambarkan karakteristik penting yang ada pada data yang telah diorganisasikan (Giandani, 2018). Data tanggapan dari responden untuk setiap instrumen variabel dilakukan berdasar nilai 
rata-rata dalam rentang nilai minimum dan maksimum disandingkan dengan nilai rata-rata dari keseluruhan instrumen variabel.

\section{Uji Asumsi Klasik}

Uji asumsi klasik yang dilakukan meliputi uji normalitas, uji multikolinearitas, dan uji heteroskedastisitas. Uji normalitas menggunakan uji statistik non-parametrik Kolmogorov Smirnov (K-S) test (Ghozali, 2013). Kriteria pengujian jika nilai signifikansi $\geq 0,05$ maka data residual berdistribusi normal. Uji multikolinieritas dilakukan dengan mengukur korelasi antar variabel bebas (independen) (Ghozali, 2013). Kriteria pengujiannya adalah nilai tolerance $\geq 0,01$ dan nilai Variance Inflation Factor (VIF) $\leq 10$ maka tidak ditemukan adanya gejala multikolinearitas. Uji heteroskedastisitas menggunakan metode glejser yang dilakukan dengan cara meregresikan semua variabel bebas (independen) (Ghozali, 2013). Jika nilai probabilitas signifikansi > 0,05 maka dapat dinyatakan tidak terjadi gejala heteroskedastisitas.

\section{Analisis Pengaruh}

Pengaruh variabel bebas (independen) terhadap variabel terikat (dependen) dilakukan dengan menggunakan analisis regresi linear berganda (Ghozali, 2013), dengan formulasi sebagai berikut:

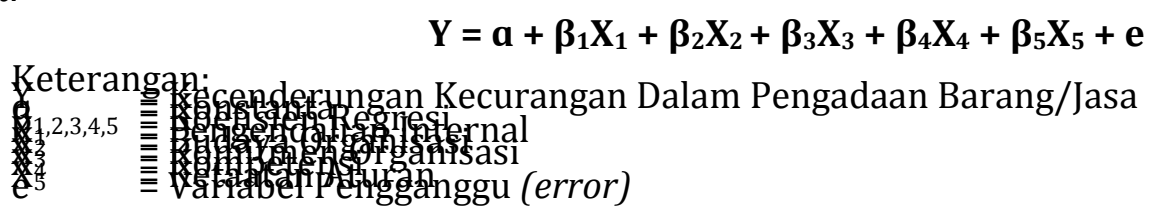

\section{Uji Ketepatan Model (Goodness of Fit Model)}

Uji ketepatan model (Ghozali, 2013) dilakukan Uji-F dengan cara membandingkan antara nilai $\mathrm{F}_{\text {hitung }}$ dengan nilai $\mathrm{F}_{\text {tabel }}$ dengan degree of freedom $\mathrm{a},(\mathrm{k}-1)$, $(\mathrm{n}-\mathrm{k})$, dengan kriteria pengambilan keputusan dalam uji F adalah jika nilai sig <0,05 maka model regresi layak digunakan.

\section{Uji Determinasi Pengaruh}

Uji determinasi pengaruh variabel independen terhadap variabel dependen diukur dengan koefisien determinasi. Koefisien determinasi $\mathrm{R}^{2}$ memiliki nilai $0-1$. Jika besarnya nilai koefisien determinasi mendekati angka 1, maka semakin tinggi kemampuan variabel independen menjelaskan variabel dependen. Adjusted $R^{2}$ adalah koefisien determinasi yang telah dikoreksi dengan jumlah variabel serta ukuran sampel akan mengurangi bias jika terjadi penambahan variabel (Suliyanto, 2011).

\section{Uji Pengaruh}

Uji pengaruh tiap variabel independen terhadap variabel dependen diukur menggunakan uji t. Uji $\mathrm{t}$ akan menunjukkan seberapa jauh pengaruh variabel independen secara parsial dalam menerangkan variabel dependen (Ghozali, 2013).

\section{HASIL DAN PEMBAHASAN}

\section{Uji Validitas}

Hasil analisis uji validitas, setiap instrumen variabel pengendalian internal, budaya organisasi, komitmen organisasi, kompetensi dan ketaatan aturan menunjukkan $r_{\text {hitung }}$ yang lebih besar dari $r_{\text {tabel }} 0,553$. Dengan demikian setiap instrumen variabel pengendalian internal, budaya organisasi, komitmen organisasi, kompetensi dan ketaatan aturan dinyatakan valid.

\section{Uji Reliabilitas}

Berdasarkan hasil analisis uji reliabilitas, nilai $\mathrm{r}_{\text {hitung }}$ masing-masing influence variable : pengendalian internal $(0,913)$, budaya organisasi $(0,860)$, komitmen organisasi $(0,824)$, kompetensi $(0,755)$, dan ketaatan aturan $(0,788)$, serta kecenderungan kecurangan dalam pengadaan barang/jasa $(0,934)$ lebih besar dari cut of value $(0,60)$, dengan demikian dapat dinyatakan reliabel sebagai alat pengumpulan data. 


\section{Statistik Deskriptif}

Angka tanggapan dari 54 responden dengan angka minimum 2,000 dan maksimum 5,000, menunjukkan angka rata-rata respons untuk masing-masing instrumen influence variable pengendalian internal 4,209 (st.dev 0,719), budaya organisasi 3,995 (st.dev 0,726), komitmen organisasi 4,090 (st.dev 0,952), Kompetensi 4,245 (st.dev 0,890), Ketaatan aturan 4,200 (st.dev 0,712), serta kecenderungan kecurangan dalam pengadaan barang/jasa 3,770 (st.dev 0,935). Angka rata-rata yang lebih besar daripada angka standar deviasi menunjukkan bahwa angka rata-rata merepresentasikan keseluruhan data dengan baik. Angka rata-rata terrendah dari influence variable dapat dimaknai bahwa influence variable tersebut yang lebih dipahami dalam mendeskripsi kecenderungan kecurangan bawahan dalam pengadaan barang/jasa.

\section{Uji Asumsi Klasik}

Hasil uji normalitas, angka K-S 1,190 dan angka asymp. sig. (2-tailed) 0,118 standardized residual variable lebih besar dari angka $\alpha(0,05)$ menunjukkan bahwa data berdistribusi normal. Berdasarkan hasil uji multikolinearitas diperoleh angka VIF dan TOL influence variable pengendalian internal (VIF= 1,361; TOL $=0,735)$, budaya organisasi $(\mathrm{VIF}=1,233 ; \mathrm{TOL}=0,811)$, komitmen organisasi $(\mathrm{VIF}=1,289$; $\mathrm{TOL}=0,776)$, kompetensi $(\mathrm{VIF}=1,265$; $\mathrm{TOL}=0,791)$ dan ketaatan aturan (VIF= 1,098; TOL= 0,911) angka VIF masing-masing lebih kecil dari 10 dan TOL lebih besar dari 0,10 yang menunjukkan bahwa dalam model regresi tidak terjadi gejala multikolinearitas. Hasil uji heteroskedastiistas, nilai signifikansi uji t variabel pengendalian internal $(0,950)$, variabel budaya organisasi $(0,216)$, komitmen organisasi $(0,604)$, kompetensi $(0,152)$ dan ketaatan aturan $(0,742)$ masing-masing lebih besar dari angka $\alpha(0,05)$, menunjukkan bahwa dalam model regresi tidak terjadi heteroskedastisitas.

\section{Analisis Pengaruh}

Berdasarkan hasil analisis regresi linier berganda diperoleh angka koefisien regresi masing-masing influence variable pengendalian internal minus 0,338 ( $\mathrm{t}_{\text {hitung }}-2,311$ ), budaya organisasi minus 0,295 ( $t_{\text {hitung }}-2,137$ ), komitmen organisasi minus 0,238 ( $t_{\text {hitung }}-2,209$ ), kompetensi minus 0,239 ( $\mathrm{t}_{\text {hitung }}-2,095$ ), ketaatan aturan minus 0,278 ( $\mathrm{t}_{\text {hitung }}-2,098$ ) dengan

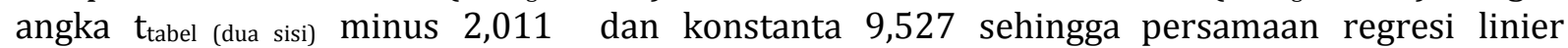
bergandanya sebagai berikut:

$$
\mathrm{Y}=9,527-0,338 \mathrm{X}_{1}-0,295 \mathrm{X}_{2}-0,238 \mathrm{X}_{3}-0,239 \mathrm{X}_{4}-0,278 \mathrm{X}_{5}
$$

\section{Uji Ketepatan Model}

Hasil uji ketepatan model diperoleh angka $F_{\text {hitung }}(11,892)>F_{\text {tabel }}$ dan angka $\operatorname{sig}(0,000$ a $)<0,05$ yang menunjukkan bahwa model regresi yang terbentuk dinyatakan tepat.

\section{Uji Determinasi Pengaruh}

Hasil uji determinasi pengaruh diperoleh koefisien determinasi (Adjusted $R^{2}$ ) sebesar 0,507 atau sebesar 50,7 persen yang berarti bahwa variabel kecenderungan kecurangan dalam pengadaan barang/jasa dapat dijelaskan bahwa influence variable pengendalian internal, budaya organisasi, komitmen organisasi, kompetensi variabel ketaatan aturan, sedangkan 49,3 persen dapat dipengaruhi oleh variabel-variabel lain seperti moralitas aparat (Noviriantini et al, 2015; dan Firdaus, 2018); kesesuaian kompensasi (Amalia, 2015; dan Frilia, 2015); serta asimetri informasi (Aranta, 2013).

\section{Uji Pengaruh}

Tabel 1. Ringkasan Hasil Uji Hipotesis.

\begin{tabular}{lrrrl}
\hline Variabel & Koefisien regresi & \multicolumn{1}{c}{$t_{\text {hitung }}$} & \multicolumn{1}{c}{$t_{\text {tabel }}$ (dua sisi) } & Kesimpulan \\
\hline Pengendalian Internal & $-0,338$ & $-2,311$ & $-2,011$ & Diterima \\
Budaya Organisasi & $-0,295$ & $-2,137$ & $-2,011$ & Diterima
\end{tabular}




\begin{tabular}{lllll} 
Komitmen Organisasi & $-0,238$ & $-2,209$ & $-2,011$ & Diterima \\
Kompetensi & $-0,239$ & $-2,095$ & $-2,011$ & Diterima \\
Ketaatan Aturan & $-0,278$ & $-2,098$ & $-2,011$ & Diterima \\
\hline
\end{tabular}

Hasil uji hipotesis menunjukkan bahwa masing-masing influence variable pengendalian internal, budaya organisasi, komitmen organisasi, kompetensi, dan ketaatan aturan secara tidak searah (negatif) berpengaruh signifikan terhadap kecenderungan kecurangan dalam pengadaan barang/jasa.

\section{Pembahasan}

Influence variable pengendalian internal secara tidak searah (negatif) berpengaruh signifikan terhadap kecenderungan kecurangan dalam pengadaan barang/jasa. Hasil tersebut didukung dengan persepsi responden yang rata-rata menyatakan setuju terhadap item instrumen penelitian. Hasil ini juga ditunjukkan dengan karakteristik individu responden dari aspek lama bekerja, pendidikan dan pelatihan yang pernah diikuti terkait dengan ruang lingkup pengendalian internal dalam pengadaan barang/jasa. Responden menyatakan bahwa panitia pengadaan barang/jasa telah melakukan pengendalian internal yang memenuhi komponen lingkungan pengendalian, penilaian risiko, kegiatan pengendalian, informasi dan komunikasi serta pemantauan dalam proses pelaksanaan pengadaan barang/jasa di Dinas Daerah Kabupaten Cilacap. Hasil penelitian ini tidak berbeda dengan hasil penelitian Arifianti et al (2015); Astari (2018); dan Artini et al (2014) yang menyatakan bahwa pengendalian internal berpengaruh signifikan terhadap kecenderungan kecurangan. Hasil penelitian ini juga dapat menjadi penguat temuan BPK bahwa sistem pengendalian internal yang baik mampu mengurangi tingkat kecurangan yang terjadi pada suatu organisasi (Kompasiana, 2016) dan secara konsep menguatkan pernyataan bahwa pencegahan kecurangan dapat dimulai dari pengendalian internal yang efektif (Tuanakotta, 2007). Dengan demikian penguatan pencegahan kecurangan terutama aspek kecenderungan untuk melakukan manipulasi dan melakukan perlakuan yang tidak semestinya terhadap aset (barang/jasa) dapat dilakukan dengan menguatkan aspek pengendalian internal yaitu lingkungan pengendalian, penilaian risiko dan aktivitas pengendalian.

Budaya organisasi menggambarkan karakteristik pada suatu organisasi. Influence variable budaya organisasi secara tidak searah (negatif) berpengaruh signifikan terhadap kecenderungan kecurangan dalam pengadaan barang/jasa. Hasil ini juga ditunjukkan dengan tanggapan responden yang rata-rata menyatakan setuju bahwa orientasi organisasi pada inovasi dan keberanian mengambil risiko, perhatian pada hal-hal rinci, orientasi pada hasil, orientasi pada orang dan tim, agresivitas serta stabilitas dapat mengeliminasi kecenderungan kecurangan. Rata-rata skor jawaban responden yang paling rendah terhadap variabel budaya organisasi pada aspek perhatian pada hal-hal rinci, orientasi pada orang, orientasi pada tim dan agresivitas. Hasil penelitian ini tidak berbeda dengan hasil penelitian Virmayani et al (2017) dan Fachrunisa (2015) yang menyatakan bahwa budaya organisasi berpengaruh signifikan terhadap kecenderungan kecurangan. Penerapan budaya organisasi yang baik dapat meminimalisasi terjadinya kecenderungan kecurangan (Siregar dan Hamdani, 2018).

Influence variable komitmen organisasi secara tidak searah (negatif) berpengaruh signifikan terhadap kecenderungan kecurangan dalam pengadaan barang/jasa. Hasil tersebut didukung dengan karakteristik responden bahwa sebagian besar responden telah bekerja sebagai PNS selama lebih dari 10 tahun (64,81 \%) dan menjadi Pejabat Pembuat Komitmen (PPK) selama 1-5 tahun (61,11 \%). Lamanya seseorang bekerja pada suatu instansi dapat menunjukkan seberapa besar komitmennya terhadap organisasi tersebut. Individu yang mempunyai komitmen tinggi akan mendahulukan kepentingan bersama daripada kepentingan sendiri. Hal ini juga akan menumbuhkan loyalitas kepada organisasi dan berpengaruh terhadap sikap profesionalitas dalam melaksanakan pekerjaan (pengadaan barang/jasa). Hasil penelitian ini tidak berbeda dengan hasil penelitian Sumbayak et al (2017) bahwa komitmen organisasi berpengaruh negatif terhadap kecenderungan kecurangan. Temuan studi Virmayani et al (2017) 
menunjukkan bahwa komitmen organisasi dapat menurunkan tingkat kecenderungan kecurangan secara signifikan. Dengan demikian penguatan pencegahan kecurangan terutama aspek kecenderungan untuk melakukan manipulasi dan melakukan perlakuan yang tidak semestinya terhadap aset (barang/jasa) dapat dilakukan dengan menguatkan aspek komitmen organisasi yaitu loyalitas pegawai kepada organisasi.

Influence variable kompetensi secara tidak searah (negatif) berpengaruh signifikan terhadap kecenderungan kecurangan dalam pengadaan barang/jasa. Responden menyatakan setuju bahwa pengetahuan panitia pengadaan barang/jasa berhubungan dengan kecenderungan kecurangan dalam pengadaan barang/jasa. Separuh lebih $(57,41 \%)$ dari jumlah responden berpendidikan S2. Hal ini menunjukkan bahwa responden memiliki pengetahuan dan pemahaman yang sangat memadai untuk melakukan tugasnya sebagai PPK. Hal tersebut juga didukung dengan aturan yang mewajibkan Panitia Pengadaan Barang/Jasa mengikuti pendidikan dan pelatihan untuk meningkatkan kompetensi mereka di bidang pengadaan barang/jasa. Hasil penelitian ini tidak berbeda dengan hasil penelitian Yanavia (2014) yang menunjukkan bahwa kompetensi Panitia Pengadaan Barang/Jasa merupakan faktor yang mempengaruhi keberhasilan suatu sistem pengadaan barang/jasa dalam mencapai tujuan yang telah ditetapkan. Kompetensi memiliki peran penting sehingga berpengaruh signifikan terhadap kecenderungan kecurangan (Wonar et al, 2018). Dengan demikian penguatan pencegahan kecurangan terutama aspek kecenderungan untuk melakukan manipulasi dan melakukan perlakuan yang tidak semestinya terhadap aset (barang/jasa) dapat dilakukan dengan menguatkan aspek kompetensi yaitu mutu personal dan pengetahuan umum.

Influence variable ketaatan aturan secara tidak searah (negatif) berpengaruh signifikan terhadap kecenderungan kecurangan dalam pengadaan barang/jasa. Responden menyatakan setuju bahwa panitia pengadaan barang/jasa wajib mengetahui peraturan tentang pengadaan barang/jasa, dan melaksanakan pekerjaan dengan tertib dan tepat waktu. Hal ini ditunjukkan dengan jenjang dan latar belakang pendidikan responden, pendidikan dan pelatihan (diklat) yang pernah diikuti responden, dan keikutsertaan responden antara lain ikut serta dalam sosialisasi mengenai peraturan dalam pengadaan barang/jasa. Hasil penelitian ini tidak berbeda dengan hasil penelitian Chandra dan Ikhsan (2015); Zulkarnain (2013); serta Wijayanti (2016) yang menunjukkan bahwa terdapat pengaruh negatif antara ketaatan aturan/hukum terhadap kecenderungan kecurangan. Dengan demikian penguatan pencegahan kecurangan terutama aspek kecenderungan untuk melakukan manipulasi dan melakukan perlakuan yang tidak semestinya terhadap aset (barang/jasa) dapat dilakukan dengan menguatkan aspek ketaatan aturan yaitu disiplin kerja.

\section{KESIMPULAN}

Berdasarkan hasil penelitian dan pembahasan dapat disimpulkan bahwa influence variable (pengendalian internal, budaya organisasi, komitmen organisasi, kompetensi, dan ketaatan aturan) secara tidak searah (negatif) berpengaruh signifikan terhadap kecenderungan kecurangan dalam pengadaan barang/jasa. Berkaitan dengan budaya organisasi, sikap etis dan tanggung jawab penuh terhadap pekerjaan oleh panitia pengadaan barang/jasa dapat dibangun dengan mengevaluasi hasil pekerjaan dan kinerja secara individu maupun dalam tim secara berkelanjutan. Berkaitan dengan komitmen organisasi, loyalitas panitia pengadaan barang/jasa dapat ditingkatkan dengan pemberian penghargaan (reward) finansial dan non-finansial. Penghargaan finansial seperti bonus atau komisi dan penghargaan non-finansial seperti pujian, promosi jabatan dan pengakuan dari organisasi atas kontribusinya dalam mewujudkan tujuan organisasi pada pelaksanaan pengadaan barang/jasa.

Berdasarkan hasil penelitian, untuk mengarahkan hubungan variabel independen dengan variabel dependen agar sesuai teori maka penelitian mengenai kecenderungan kecurangan dapat dikaji lebih lanjut menggunakan variabel independen lain dengan pendekatan psikologis serta menggunakan teknik analisis data lainnya yang melibatkan sumber data atau responden yang cakupannya lebih luas. 


\section{DAFTAR PUSTAKA}

Abdullahi, Noor dan Noorhayati Mansor. 2015. Fraud Triangle Theory and Fraud Diamond Theory Understanding the Convergent and Divergent For Future Research. International Journal of Academic Research in Accounting, Finance and Management Sciences. 5.4. 38-45. Diakses dari www.hrmars.com

Adinda, Yanita Maya. 2015. Faktor Yang Mempengaruhi Terjadinya Kecurangan (Fraud) Di Sektor Pemerintahan Kabupaten Klaten. (Skripsi). Tersedia di https://lib.unnes.ac.id

Afsari, Siti Fitriani. 2016. Analisis Faktor-Faktor Yang Mempengaruhi Kecenderungan Kecurangan (Fraud) di Sektor Pemerintahan Berdasarkan Teori Fraud Triangle: Persepsi Pegawai Pemerintahan (Studi pada SKPD di Kabupaten Jember). (Skripsi). Tersedia dari https://repository.unej.ac.id

Akbar et al. 2012. Fraud Pengadaan Barang/Jasa. CBAM-FE. 1. 1213-1238. Diakses dari https://lppmunisula.com

Amalia, Reda Dista. 2015. Pengaruh Keefektifan Pengendalian Internal, Kesesuaian Kompensasi, Moralitas Aparat dan Asimetri Informasi Terhadap Kecenderungan Kecurangan Akuntansi (Studi Empiris pada Pemerintah Daerah Kabupaten Siaik Sri Indrapura). JOM FEKON. 2. 1-15. Diakses dari https://jom.unri.ac.id

Aranta, Petra Zulia. 2013. Pengaruh Moralitas Aparat dan Asimetri Informasi Terhadap Kecenderungan Kecurangan Akuntansi (Studi Empiris Pemerintah Kota Sawahlunto). (Skripsi). Fakultas Ekonomi. Universitas Negeri Padang. Tersedia dari https://ejpurnal.unp.ac.id

Arifianti et al. 2015. Perspektif Triangle Fraud Theory Dalam Pengadaan Barang/Jasa di Pemerintah Provinsi NTB. inFestasi. 11. 195-213. Diakses dari https://infestasi.trunojoyo.ac.id

Ariyanti, Fiki. (2019, September 14). Gak Usah 'Alergi' Kuliah S2, Ini Keuntungan Punya Gelar Master Buat Kariermu. Cermati.com. Diakses dari https://www.cermati.com/artikel/-gak-usah-'alergi'-kuliahs2-ini keuntungan-punya-gelar-master-buat-kariermu

Artini et al. 2014. Pengaruh Budaya Etis Organisasi dan Efektifitas Pengendalian Internal Terhadap Kecenderungan Kecurangan Akuntansi Pada SKPD Kabupaten Jembrana. E-Jurnal S1 Akuntansi Universitas Pendidikan Ganesha. 2. Diakses dari https://ejurnal.undiksha.ac.id

Astari, Julian Dini. (2018). Analisis Faktor-Faktor yang Mempengaruhi Kecenderungan Kecurangan Akuntansi (Studi pada OPD Kabupaten Kuantan Singingi). JOM FEKON. 5. 1-15. Diakses dari https://jom.unri.ac.id

Bateman, Thomas S dan Scott A Snell. 2007. Manajemen: Kepemimpinan dan Kolaborasi dalam Dunia yang Kompetitif (Buku 1). Jakarta: Salemba Empat.

Black, Henry Campbell. (1990) Black's Law Dictionary Centennial Sixth Edition. St.Paul, Minn: West Publishing co. Diakses dari http://books.google.com

Chandra, Devia Prapnalia dan Sukardi Ikhsan. 2015. Determinan Terjadinya Kecenderungan Kecurangan Akuntansi (Fraud) pada Dinas Pemerintah Se Kabupaten Grobogan. Accounting Analysis Journal. 3. 361-369. Diakses dari https://jurnal.unnes.ac.id

Cressey, D. R. (1953). Other People's Money: A Study In The Social Psychology of Embezzlement. The Free Press. Diakses dari https://psycnet.apa.org

Crowe, Howarth LLP. 2011. Why The Fraud Triangle Is No Longer Enough. Horwarth Crowe LLP. Diakses dari http://aiba-us.org

Damanik, Saskia. (2016, Aprl 21). Wanita vs pria, Siapa Yang Lebih Unggul Dalam Dunia Kerja?. Glitzmedia.co. Diakses dari https://glitzmedia.co/post/leisure/carrer-money/wanita-vs-pria-siapayang-lebih-unggul-dalam-dunia-kerja

Delfi, Tiara et al. 2014. Pengaruh Efektifitas Pengendalian Internal dan Kesesuaian Kompensasi Terhadap Kecenderungan Kecurangan Akuntansi (Survey Pada Perusahaan BUMN Cabang Pekanbaru). JOM FEKON. 1. 2. Diakses dari https://jom.unri.ac.id

Fachrunisa, Aisah. 2015. Pengaruh Keefektifan Pengendalian Internal, Keadilan Distributif, Keadilan Prosedural dan Budaya Etis Organisasi Terhadap Kecenderungan Kecurangan (Fraud) Akuntansi 
(Studi Empiris Pada SKPD Kabupaten Kampar). JOM FEKON. 2. 1-15. Diakses dari https://jom.unri.ac.id

Firdaus, M Hildan Zaka. 2018. Analisis Faktor-Faktor Yang Mempengaruhi Kecenderungan Pegawai Melakukan Kecurangan atau Fraud Pada Sektor Pemerintahan (Studi Kasus Pada Pemerintahan di Kabupaten Klaten). (Skripsi). Tersedia dari https://dspace.uii.ac.id

Frilia, Figna. 2015. Pengaruh Asimetri Informasi, Sistem Pengendalian Intern dan Kesesuaian Kompensasi Terhadap Kecenderungan Kecurangan Akuntansi (Studi Empiris pada Bank Swasta di Kota Pekanbaru). JOM FEKON. 2. Diakses dari https://jom.unri.ac.id

Ghozali, Imam. 2013. Aplikasi Analisis Multivariate Dengan Program IBM SPSS 21 Update PLS Regresi. Semarang: Badan Penerbit Universitas Diponegoro.

Giandani, Annisara Shifa 2018. Analisis Pengaruh Penerapan Sistem Pengendalian Internal Pemerintah, Gaya Kepemimpinan, Budaya Organisasi, Locus of Control, dan Komitmen Organisasi Terhadap Kinerja Unit Pengadaan Barang/Jasa (Studi Pada OPD Kota Tegal). (Skripsi). Fakultas Ekonomi dan Bisnis. Universitas Jenderal Soedirman. Purwokerto.

Hall, J. A. 2011. Accounting Information Systems. Mason: South-Western Cengage Learning. Hertanto, Eko. 2014.

Indratama, Janitra Yoga. 2018. Analisis Persepsi Periviu Tentang Aspek Mandatory dan Non-Mandatory Yang Mempengaruhi LKPD Yang Berkualitas. (Skripsi). Fakultas Ekonomi dan Bisnis. Universitas Jenderal Soedirman. Purwokerto.

Indriani et al. (2016). Penerapan Konsep Fraud Diamond Theory dalam Mendeteksi Perilaku Fraud. Simposium Nasional Akuntansi XIX Lampung. Diakses dari https://lib.ibs.ac.id

Irphani, Adi. 2017. Pengaruh Tekanan, Keefektifan Pengendalian Internal, Perilaku Tidak Etis, dan Jabatan Dalam Pengelola Keuangan Terhadap Fraud (Studi Pada SPKD Kota Metro). (Skripsi). Tersedia dari https://digilib.unila.ac.id

Ivancevich et al. 2007. Perilaku dan Manajemen Organisasi (Edisi 7). Jakarta: Erlangga.

Jatiningtyas, Nurani dan Kiswara Endang. 2011. Analisis Faktor-Faktor Yang Mempengaruhi Fraud Pengadaan Barang/Jasa Pada Lingkungan Instansi Pemerintah di Wilayah Semarang. (Skripsi). Tersedia dari https://eprints.undip.ac.id

Kibtiyah et al. 2017. Pengaruh Kompetensi, Budaya Organisasi dan Gaya Kepemimpinan pada Efektifitas Sistem Pengendalian Intern Pengadaan Barang/Jasa Pemerintah. E-jurnal Ekonomi dan Bisnis Universitas Udayana. 5. 1877-1908. Diakses dari https://ojs.unud.ac.id

Kementerian Hukum dan Hak Asasi Manusia RI. 2008. Peraturan Pemerintah Nomor 60 Tahun 2008 tentang Sistem Pengendalian Internal Pemerintah (PP Nomor 60 tahun 2008). Diakses dari http://jdih.kemenkeu.go.id

Kurniawan, Adi. (2018. April 6). Wow ini 11 temuan BPK atas Kinerja Pemkab Cilacap. Serayunews.com. Diakses dari https://serayunews.com/berita/wow-ini-temuan-BPK-atas-kinerja-pemkab-cilacap/

Kusnandar, Viva Budy. (2019. September 9). Berapa Jumlah Penduduk Usia Produktif Indonesia?. Databoks. Diakses dari https://databoks.katadata.co.id/datapublish

Lacaden, Bernadeth Marsella Giovanni. (2015, Desember 1). Pentingnya Sistem Pengendalian Internal dalam Akuntansi. Kompasiana. Diakses dari https://kompasiana.com/bmgiovanni/ 565dc3ef47e615a36b44b57/pentingnya-sistem-pengendalian-internal-dalam-akuntansi?page=all

Mathis, R.L dan Jackson, J.H. 2002. Human Resource Management. Alih Bahasa. Jakarta: Salemba Empat

Maulidina, Ratih dan Maya Ariyanti. 2016. Analisis Ekuitas Merek Smartphone Apple dan Samsung Pada Konsumen Muda di Indonesia (Kesadaran Merek, Pesepsi Kualitas, Asosiasi Merek, Loyalitas). Eproceedings of Management. Diakses dari https://telkomuniversity.ac.id

Meyer, J dan N Allen. 1997. Testing the "side bet theory" of Organizational Commitment: Some Methodological Coniderations. Journal of Applied Psychology. 69. 372-378.

Moeller, R. 2009. Brink's Modern Internal Auditing (7th Edition). New Jersey: John Wiley \& Sons Inc. 
Najahningrum, Anik Fatun. 2013. Faktor-Faktor yang Mempengaruhi Fraud: Persepsi Pegawai Dinas Provinsi DIY. Accounting Analysis Journal. 2 . 259-267. Diakses dari https://jurnal.unnes.ac.id

Nisa, Aghnia Rahmatun. (2016. Juni 14). Mengapa SPI, Pengawasan, dan Audit Dibutuhkan oleh Pemerintah?. Kompasiana. Diakses dari https://www.kompasiana.com/aghniarn/

Noviriantini et al. 2015. Pengaruh Budaya Etis Organisasi dan Moralitas Aparat Terhadap Kecenderungan Kecurangan (Fraud) Akuntansi (Studi Empiris pada SKPD Kabupaten Jembrana). E-journal S1 Akuntansi Universitas Ganesha .3.1-12. Diakses dari https://ejournal.undiksha.ac.id

Pejabat Pengelola Informasi dan Dokumentasi. 2018. Data Informasi Web Link OPD Kabupaten Cilacap. Diakses tanggal 8 Maret 2019, dari http://ppid3.cilacapkab.go.id

Peraturan Presiden Republik Indonesia Nomor 16 Tahun 2018 tentang Pengadaan Barang/Jasa (Perpres No 16 Tahun 2018). Diakses dari https://jdih.lkpp.go.id

Porter, Lyman et al. 1974. Organizational Commitment, Job Satisfaction, and Turnover Among Psychiatric Technicians. Journal of Applied Psychology. 59. 603-609. ISSN: 0021-9010.Diakses dari http://insights.ovid.com

Pristiyanti, Ika Ruly. 2012. Persepsi Pegawai Instansi Pemerintah Mengenai Faktor-Faktor yang Mempengaruhi Fraud di Sektor Pemerintahan. Accounting Analysis Journal. 1. 1-14. Diakses dari https://jurnal.unnes.ac.id

Purwitasari, Anggit. 2013. Pengaruh Pengendalian Internal dan Komitmen Organisasi dalam Pencegahan Fraud Pengadaan Barang (Survey pada 5 Rumah Sakit di Bandung). (Skripsi). Tersedia dari https://repository.widiyatama.ac.id

Randiza, Ikhsan. 2016. Pengaruh Pengendalian Internal, Asimetri Informasi, Moralitas Aparat Pemerintah dan Ketaatan Aturan Terhadap Kecenderungan Kecurangan Akuntansi (Studi Kasus Pada SKPD Kabupaten Indragiri Hilir). JOM FEKON. 3. 1108-1122. Diakses dari https://jom.unri.ac.id

Sarwono, Jonathan. 2011. Buku Pintar IBM SPSS Statistics 19. Jakarta: PT Elex Media Komputindo

Siegel, Joel G dan Jae K Shim. 1999. Kamus Istilah Akuntansi. Jakarta: PT Elex Media Komputindo

Singleton, Tommie dkk. 2006. Fraud Auditing and Forensic Accounting Third Edition. New Jersey: John Wiley \& Sons Inc

Siregar, Muchamad Ikhsan dan Mufid Hamdani. 2018. Pengaruh Kesesuaian Kompensasi, Keefektifan Sistem Pengendalian Internal, Budaya Organisasi, dan Kompetensi Terhadap Fraud (Studi pada Satuan Kerja Vertikal Kementerian Keuangan Provinsi Lampung). Jurnal Ekonomi Global Masa Kini Mandiri. 9. 30-37. Diakses dari https://ejurnal.uigm.ac.id

Suliyanto. 2005. Ekonometrika Terapan: Teori \& Aplikasi dengan SPSS. Yogyakarta: Andi.

2011. Ekonometrika Terapan: Teori\& Aplikasi dengan SPSS. Yogyakarta: Andi.

Sumbayak et al. 2017. Pengaruh Keadilan Organisasi, Sistem Pengendalian Intern, Komitmen Organisasi dan Gaya Kepemimpinan Terhadap Kecurangan (Fraud) (Studi Empiris Pada Kantor Cabang Utama Perusahaan Leasing di Kota Pekanbaru). JOM FEKON. 4. 3168-3182. Diakses dari https://jom.unri.ac.id

Susandra, F dan S Hartina. 2017. Analisis Faktor-Faktor Yang Mempengaruhi Kecenderungan Fraud Pada SKPD di Kota Bogor. Jurnal Akunida. 3. 33-55. Diakses dari https://ojsunida.ac.id

Tandilangi, A. 2015. Pengaruh Kompetensi, Independensi, dan Pengalaman Kerja Terhadap Kualitas Hasil Audit Pada Inspektorat Kabupaten Toraja. (Skripsi). Tersedia di https://unhas.ac.id

Tarigan, Lorensia B R. 2016. Pengaruh Moralitas Inidividu, Asimetri Informasi, Efektifitas Pengendalian Internal dan Ketaatan Aturan Akuntansi Terhadap Kecenderungan Kecurangan Akuntansi (Studi pada BUMD Provinsi Riau). JOM FEKOM. 3. 896-909. Diakses dari https://jom.unri.ac.id

Tim Indonesia Corruption Watch. (2019, Februari 7). Tren Penindakan Kasus Korupsi Tahun 2018. Indonesia Corruption Watch. Diakses dari https://antikorupsi.org/id/tren/tren-penindakan-kasus$\underline{\text { korupsi-2018 }}$

Tim Suara Merdeka. (2018, Oktober 17). Inspektorat Sampaikan 630 Temuan. Suara Merdeka. Diakses dari https://suaramerdeka.com/smcetak/inspektorat-sampaikan-630-temuan/134861/ 
Tuanakotta, Theodorus M. 2007. Akuntansi Forensik dan Audit Investigatif. Jakarta: Lembaga Penerbit Fakultas Ekonomi Universitas Indonesia

Virmayani et al. 2017. Pengaruh Kesesuaian Kompensasi, Asimetri Informasi, Budaya Etis Organisasi, dan Komitmen Organisasi Terhadap Kecenderungan Kecurangan (Fraud) Akuntansi Pada Koperasi Simpan Pinjam Se Kecamatan Buleleng. E-Jurnal S1 Akuntansi Universitas Pendidikan Ganesha. 7. Diakses dari https://ejurnal.undiksha.ac.id

Wijayanti, Wieke. 2016. Pengaruh Peraturan Hukum, Keefektifan Pengendalian Intern, Kesesuaian Kompensasi dan Budaya Etis Manajemen Terhadap Kecurangan (Fraud) di Instansi Pemerintahan (Studi pada SKPD Kabupaten Bondowoso). Journal of Undergraduate Thesis, Universitas Muhammadiyah Jember. Diakses dari https://unmuhjember.ac.id

Wilopo. 2016. Analisis Faktor-Faktor yang Berpengaruh Terhadap Kecenderungan Kecurangan Akuntansi: Studi pada Perusahaan Publik dan BUMN di Indonesia. Jurnal Riset Akuntansi Indonesia. 12-13. Doi 10.1001/jama.1994.03520170077040

Wolfe, David T dan Dana R Hermanson. 2004. The Fraud Diamond: Considering the Four Elements of Fraud. CPA Journal. 74. 12. 38-42. 07328435

Wonar, Klara et al. 2018. Pengaruh Kompetensi Aparatur Desa, Ketaatan Pelaporan Keuangan dan Sistem Pengendalian Intern Terhadap Pencegahan Fraud Dengan Moral Sensitivity Sebagai Variabel Moderasi. Jurnal Akuntansi, Audit Riset. 1. 63-89. Diakses dari https: //ejournal.maksi-uncen.ac.id

Yanavia, Nike Lolita. 2014. Analisis Faktor-Faktor Yang Mendorong Terjadinya Fraud Pengadaan Barang/Jasa Pada Lingkungan Instansi Pemerintah di Provinsi Sumatera Barat. Jurnal Akuntansi. Diakses dari https://ejournal.unp.ac.id

Zainal, Rizki. 2013. Pengaruh Efektivitas Pengendalian Internal, Asimetri Informasi dan Kesesuaian Kompensasi Terhadap Kecenderungan Kecurangan Akuntansi (Studi Empiris Cabang Bank Pemerintah dan Swasta di Kota Padang). (Skripsi). Fakultas Ekonomi. Universitas Negeri Padang. Tersedia dari https://ejournal.unp.ac.id

Zulkarnain, Rifqi Mirza. 2013. Analisis Faktor Yang Mempengaruhi Terjadinya Fraud Pada Dinas Kota Surakarta . Accounting Analysis Journal. Diakses dari https://jurnal.unnes.ac.id

(https://kbbi.kemdikbud.go.id) 